\title{
Soil organic carbon assessment under different land uses in Cauvery delta zone of Tamil Nadu, India
}

\author{
Surya Prabha, A.C.* \\ Silviculture and Forest Management Division, Institute of Forest Genetics and Tree Breeding, \\ Coimbatore-641002 (Tamil Nadu), India \\ Velumani, R. \\ Silviculture and Forest Management Division, Institute of Forest Genetics and Tree Breeding, \\ Coimbatore-641002 (Tamil Nadu), India \\ Senthivelu, $M$. \\ Maize Research Station, Vagarai, Tamil Nadu Agricultural University, Coimbatore-641003 \\ (Tamil Nadu), India \\ Arulmani, $\mathrm{K}$. \\ Silviculture and Forest Management Division, Institute of Forest Genetics and Tree Breeding, \\ Coimbatore-641002 (Tamil Nadu), India \\ Pragadeesh, S. \\ Silviculture and Forest Management Division, Institute of Forest Genetics and Tree Breeding, \\ Coimbatore-641002 (Tamil Nadu), India \\ *Corresponding author. E-mail: acsuryaprabha19@gmail.com
}

\section{How to Cite}

Surya Prabha, A.C. et al. (2020). Soil organic carbon assessment under different land uses in Cauvery Delta Zone of Tamil Nadu, India. Journal of Applied and Natural Science, 12(4):478- 483. https://doi.org/10.31018/jans.v12i4.2372

\begin{abstract}
Soil organic carbon (SOC) plays a vital role in soil fertility and is important for its contributions to mitigation and adaptation to climate change. The present study was undertaken to estimate the SOC stock in soils under different land uses of Cauvery Delta zone of Tamil Nadu. Four different land uses were selected for the study viz, Forests, Agriculture, Agro-forestry and Plantations. Soil samples were collected from Madukkur and Kalathur soil series of Cauvery Delta zone for soil carbon analysis. The soil samples were fractionated into three aggregate size classes viz., macro-aggregates (250-2000 $\mu \mathrm{m})$, micro-aggregates (53$250 \mu \mathrm{m})$ and silt and clay sized fraction $(<53 \mu \mathrm{m})$. At 0-30 cm depth, the forest land use stored the maximum SOC stock in the different size fractions viz. macro-sized fraction $\left(73.0 \mathrm{Mg} \mathrm{ha}^{-1}\right)$, a micro-sized fraction $\left(76.0 \mathrm{Mg} \mathrm{ha}^{-1}\right)$ and silt+clay sized fraction $\left(77.0 \mathrm{Mg} \mathrm{ha}^{-1}\right)$ in Madukkur series. Agriculture land use registered the lowest SOC stock. Among the different size fractions, silt+clay sized fraction $(<53 \mu \mathrm{m})$ retained the maximum SOC in all the land uses. In Kalathur series also, maximum soil organic carbon stock was recorded in forest land use. The data generated in the study will be beneficial to the user groups viz., farmers in identifying the most suitable land use for enhancing the storage of soil organic carbon thereby improving yields of crops andtrees.
\end{abstract}

Keywords: Land use, Organic carbon stock, Soil organic carbon, Soil series

\section{INTRODUCTION}

Global climatic conditions due to human activities have directed towards utilizing soils as a resource to both mitigate and adapt to climate change. The role of soils and SOC in climate change adaptation and mitigation has been widely accepted and demonstrated in various studies (Scharlemann et al., 2014). At the global level, Soil Organic Carbon (SOC) stocks are estimated at an average of $1,500 \pm 230 \mathrm{Pg} \mathrm{C}$ in the $100 \mathrm{~cm}$ of soil, and this is nearly twice as that of atmospheric carbon $(828 \mathrm{Pg} \mathrm{C})$ and thrice as that of terrestrial vegetation (500 Pg C) (Quere et al., 2016). The Intergov- ernmental Panel on Climate Change identified creation and strengthening of carbon sinks in the soil as a clear option for increasing removal of $\mathrm{CO}_{2}$ from the atmosphere and has recognized soil organic carbon pool as one of the five major carbon pools for the Land Use, Land Use Change in Forestry (LULUCF) sector (IPCC, 2003). As an indicator of soil health, SOC plays a vital role by contributing to climate change mitigation and adaptation, and achievement of the Sustainable Development Goals (SDGs) (Clara et al., 2017). Enhanced capture and storage of atmospheric $\mathrm{CO}_{2}$ in different land-use systems can be a successful approach for reducing its concentration while 
also improving the quality of soil (Kenye et al., 2019). There exists considerable spatial variability according to land uses and soil depths in SOC content. Land use and soil management significantly influence the amount of soil organic carbon and may lead to both losses and gains of soil organic carbon (Wiesmeier et al. 2015). Soils of the world are potentially viable sinks for atmospheric carbon and may significantly contribute to the mitigation of global climate change (Venkanna et al. 2014). Spatially distributed estimates of SOC pools and soil carbon sequestration are important requirements for understanding the role of soils in the global carbon cycle and for assessing potential biosphere responses to climatic change or variation (Lal et al., 2012).

In general, undisturbed forest ecosystems are highly productive and accumulate more biomass and carbon per unit area compared to other land-use systems like agriculture (Devagiri et al. 2013). The extent of soil carbon retention in soils depends, on the nature of soil aggregation (Haile et al., 2010). It can be short-term storage in macro-aggregates (>250 $\mu \mathrm{m}$ diameter) and long-term storage in micro-aggregates (<250 $\mu \mathrm{m}$ diameter) including the widely accepted stability of carbon stored in the smallest size class, the silt and clay size fraction $(<53 \mu \mathrm{m})$. In this context, it is ideal for studying and estimating, for any given ecosystem, the current SOC stocks to determine a soil's carbon sequestration potential.

Studies on assessment of soil organic carbon stock under different land use in Cauvery Delta Zone, India using IPCC guidelines are lacking. Therefore, the present study was aimed to assess the carbon stock in dominant soil series under different land-use systems in the Cauvery Delta zone of Tamil Nadu.

\section{MATERIALS AND METHODS}

The study was conducted in the Cauvery Delta zone (CDZ) of Tamil Nadu which lies in the eastern part of Tamil Nadu between $10^{\circ} 00^{\prime}-11^{\circ} 30^{\prime}$ North latitude and $78^{\circ} 15^{\prime}-79^{\circ} 45^{\prime}$ East longitude (Fig.1). It is bounded by the Bay of Bengal on the East and the Palk Strait on the South, Tiruchirappalli district on the west, Perambalur and Ariyalur districts on the North West, Cuddalore district on the North and Puddukkottai district on the South West. CDZ has a total geographic land area of 14.47 lakh ha which is equivalent to $11 \%$ of the State's area of 130.33 lakh hectares.

Soil sampling: The study aimed to assess the carbon stock in dominant soil series under different land-use systems in the Cauvery Delta zone of Tamil Nadu. Out of the different land uses existing in the CDZ, four land uses were selected for our study viz, Agriculture, Agroforestry, Plantation and Forest. Agriculture, agroforestry and plantation land use included lands of private landowners. The forest land was a natural dry deciduous forest, and in agriculture land, rice was the major crop under cultivation. Soil samples (98 nos.) associated with two dominant soil series viz, Madukkur and Kalathur of CDZ were collected from various land uses adopting random sampling technique. Kalathur Series consisted of very dark grey-brown, very deep calcareous soils and it was fine-textured Cauvery river alluvium clay. Madukkur series consisted of very deep brown soil, derived from the laterite parent materials. Soil samples were collected at four depths viz., 0-30, $30-50,50-80$ and $80-100 \mathrm{~cm}$ and from three plots under each land use covering the CDZ of Tamil Nadu. The design adopted was Factorial Randomized Block Design (FRBD). The soil samples were then air-dried, mixed well and passed through a $2 \mathrm{~mm}$ sieve for the analysis of soil organic carbon. An area of $0.5 \mathrm{~m} \mathrm{x}$ $0.5 \mathrm{~m}$ was removed and a pit of $30 \mathrm{~cm}$ wide, $50 \mathrm{~cm}$ in length and $100 \mathrm{~cm}$ deep was dug at each sampling point. The soil was scrapped from three sides of the pit with the help of a kurpee at each depth. The soil was mixed thoroughly and transferred to a polythene bag with proper labelling. Latitude, longitude and altitude of each sampling point were recorded by GPS.

Soil analysis: The soil samples were fractionated into three aggregate size classes viz., macro-aggregates (250-2000 $\mu \mathrm{m})$, micro-aggregates $(53-250 \mu \mathrm{m})$ and silt and a clay-sized fraction $(<53 \mu \mathrm{m})$ according to the procedure from Six et al., (2002). Each soil sample was submerged in de-ionized water for about five minutes and then placed on top of $250 \mu \mathrm{m}$ sieve to release the air that is trapped inside soil pores. The sieving was done manually. The fraction remaining on the top of a $250 \mu \mathrm{m}$ sieve was collected in a hard plastic pan and allowed to oven-dry at $65^{\circ} \mathrm{C}$ and weighed. Water plus soil $<250 \mu \mathrm{m}$ was poured through a $53 \mu \mathrm{m}$ sieve, and the same sieveing procedure was repeated. The overall procedure yielded a water-stable, macrosized fraction 250-2000 $\mu \mathrm{m}$; a micro-sized fraction 53$250 \mu \mathrm{m}$, and silt+clay sized $<53 \mu \mathrm{m}$ fraction. The fractionated soil samples were used for the estimation of organic carbon. The total number of soil samples analyzed after fractionation was 294. Soil organic carbon (\%) was estimated by standard Chromic acid wet oxidation method of Walkley and Black (1934). For the estimation of bulk density ( $\mathrm{g} / \mathrm{cc}$ ), two to three clods of $2 \mathrm{~mm}$ size were collected from each pit, and bulk density was estimated by the wax coating (clod) method. The per cent of coarse fragments was quantified by visual observation of the area occupied by coarse fragments. Soil organic carbon stock was calculated by the equation as suggested by IPCC Good Practice Guidelines for LULUCF (2003).

$$
\begin{aligned}
& \text { Horizon=n Horizon=n } \\
& \mathrm{SOC}=\sum \mathrm{SOC}=\sum\left([\mathrm{SOC}] \quad{ }^{*} \text { Bulk density * Depth * }(1-\mathrm{C} \text { frag }){ }^{*} 100\right) \ldots . . . . \mathrm{Eq} .1 \\
& \text { Horizon=1 Horizon=1 horizon }
\end{aligned}
$$

Horizon = a distinct layer of soil, parallel with the land surface

SOC $=$ Representative soil organic carbon content for 
the forest type and soil of interest, tonnes $\mathrm{C} \mathrm{ha}^{-1}$.

SOC $=$ Soil organic carbon content for a constituent soil horizon, tonnes $\mathrm{C}$ ha $^{-1}$

\section{Horizon}

[SOC] = Concentration of SOC in a given soil mass obtained from analysis, $\mathrm{g} \mathrm{C}(\mathrm{kg} \text { soil })^{-1}$

Bulk density = Soil mass per sample volume, tonnes soil $\mathrm{m}^{-3}$ (equivalent to $\mathrm{Mg} \mathrm{m}^{-3}$ )

Depth $=$ Horizon depth or thickness of soil layer, $m$

C frag $=\%$ volume of coarse fragments $/ 100$, dimensionless.

All statistical tests were performed with SPSS ${ }^{\circledR} 19.0$ version statistical software. Wherever the treatment differences were found significant, the critical differences were worked out at 5 per cent probability and values were furnished. The treatment differences that are nonsignificant were indicated as Non-Significant (NS).

\section{RESULTS AND DISCUSSION}

Soil represents the major reservoir of terrestrial carbon pool and the amount of carbon stored in soil organic matter is one of the largest and most dynamic reservoirs of carbon in the global carbon cycle. Soil organic carbon stock under different land uses in macro-sized fraction, micro-sized fraction and silt+clay sized fraction in Madukkur series is presented in Fig.2, 3 and 4 . SOC stock under different land uses varied significantly $(p<0.05 \%)$ at different soil depths. In forest land use, the SOC stock varied from $73.0 \mathrm{Mg}$ ha ${ }^{-1}$ at $0-30 \mathrm{~cm}$ depth to $52.5 \mathrm{Mg} \mathrm{ha}^{-1}$ at $80-100 \mathrm{~m}$ depth in macro-sized fraction. In plantations the SOC stock varied from $26.4 \mathrm{Mg} \mathrm{ha}^{-1}$ at $0-30 \mathrm{~cm}$ depth to $15.8 \mathrm{Mg}$ $\mathrm{ha}^{-1}$ at 80-100 $\mathrm{m}$ whereas, in agro-forestry land use the SOC stock varied from $30.1 \mathrm{Mg} \mathrm{ha}^{-1}$ at $0-30 \mathrm{~cm}$ depth to $24.7 \mathrm{Mg} \mathrm{ha}^{-1}$ at 80-100 m. Kenye et al. (2019) also reported that natural forest recorded the highest mean SOC concentration with $2.74 \%$ at $0-45 \mathrm{~cm}$ depth and lowest in the bamboo plantation (1.09\%) in land uses of Mizoram. Comparison of SOC in the forest and agriculture land gives an understanding of the management effect on SOC stock. In our study, the forest land was a natural dry deciduous forest, and in agriculture land, rice was the major crop under cultivation. Forest land use recorded the maximum SOC stock among all the land uses studied. Soil organic carbon stock was found to decrease significantly $(<0.05 \%)$ with increasing depth, which ranged from 73.0 to $52.5 \mathrm{Mg} \mathrm{ha}^{-1}, 76$ to $54.6 \mathrm{Mg} \mathrm{ha}^{-1}$ and 77.2 to $57.8 \mathrm{Mg} \mathrm{ha}^{-1}$ in the different soil fractions of forest land use. It may be due to less leaching of dissolved organic content and hence less accumulation at lower depths. The rate at which SOC becomes available is related to the soil organic matter fraction in which it resides. At $0-30 \mathrm{~cm}$ depth, the forest land use stored the maximum SOC stock in the different size fractions viz. macro-sized fraction (73.0 $\mathrm{Mg} \mathrm{ha}^{-1}$ ), a micro-sized fraction (76.0 Mg ha ${ }^{-1}$ ) and silt+clay sized fraction (77.0 $\left.\mathrm{Mg} \mathrm{ha}^{-1}\right)$. This was followed by plantation, agroforestry and agriculture land use. The findings are similar to the work of Sahoo et al. (2019) who conducted a study on SOC pools in a different land-uses of Mizoram and reported total organic carbon was highest $(2.75 \%)$ in natural forest and lowest in grassland $(1.31 \%)$ and decreased with increasing depth.

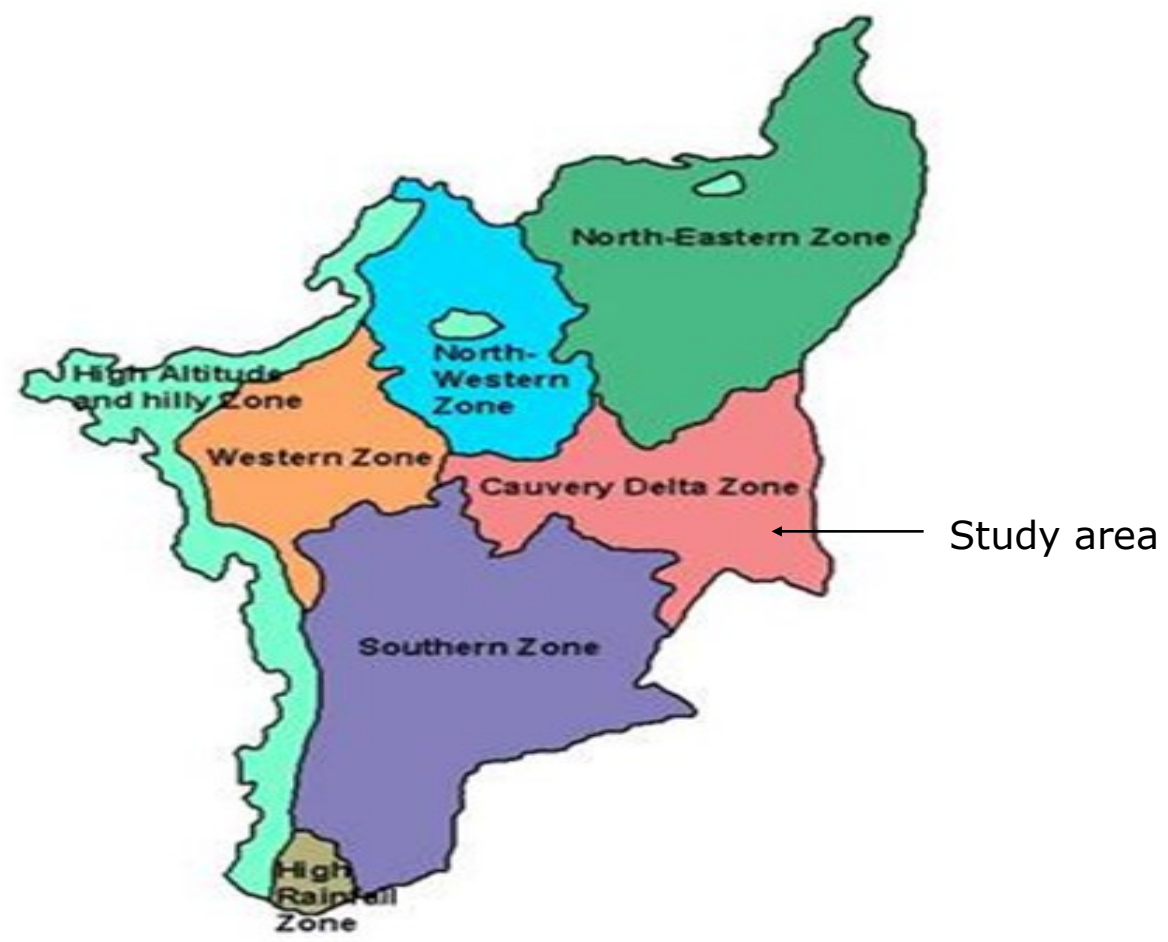

Fig.1. Map showing the study area of Cauvery delta zone of Tamil Nadu. 
The upper 0-30 $\mathrm{cm}$ soil recorded higher SOC stock than in other soil depths of the same land use. Higher SOC stock in top layer could be due to high organic matter content, low soil disturbance, greater root biomass and addition of leaf litter. The results are in conformity with the findings of Bajracharya (2004) who conducted a study on the SOC stocks in Nepal and concluded that land use had a significant effect on the SOC content in the soil profile and soils under natural vegetation had a higher SOC content in soil compared to cultivated soil. In a study conducted in northern India, there was a loss of $21-36 \%$ of total organic carbon in cultivated soils as compared to uncultivated soils (Benbi et al. 2014).

In Kalathur series also, a similar pattern of carbon storage was recorded, where, maximum soil organic carbon stock was registered under forest land use (70.7 $\mathrm{Mg} \mathrm{ha}^{-1}$ ) in macro-sized fraction, a micro-sized fraction $\left(74.5 \mathrm{Mg} \mathrm{ha}^{-1}\right.$ ) and silt+clay sized fraction (77.2 $\mathrm{Mg} \mathrm{ha}^{-1}$ ) at $0-30 \mathrm{~cm}$ depth followed by agroforestry and plantation (Fig. 5, 6 and 7). SOC stock under different land uses varied significantly ( $p$ $<0.05 \%$ ) at different soil depths. Higher organic input from litterfall and lower soil disturbance compared to cultivated land might have contributed to the higher amount of soil organic carbon (SOC) stock under forest land use at $0-30 \mathrm{~cm}$ depth in the two dominant soil series viz. Madukkur and Kalathur. Our results are consistent with the reports of Koppad and Tikhile (2014) who studied the carbon sequestration in different land uses such as plantations, forests, agriculture of Uttar Kannada district of Karnataka and reported that the carbon mitigation potential in soils of dense forest was 2.78 times more in Sirsi and 2.86 times more in Siddapur taluk as compared to Agriculture soil and was followed by horticulture plantation. The lowest SOC was recorded in Agriculture land (76.50 t/ha).

In our study, the forest land use (dry deciduous forest) recorded significantly $(<0.05 \%)$ higher SOC stock than the other land uses studied. In macro-sized fraction, the SOC stock varied from $70.7 \mathrm{Mg} \mathrm{ha}^{-1}$ at $0-30 \mathrm{~cm}$ depth to $47.4 \mathrm{Mg} \mathrm{ha}^{-1}$ at $80-100 \mathrm{~m}$ depth. The SOC stock in micro-sized fraction ranged from $74.5 \mathrm{Mg} \mathrm{ha}^{-1}$ at $0-30 \mathrm{~cm}$ depth to $48.8 \mathrm{Mg} \mathrm{ha}^{-1}$ at $80-100 \mathrm{~m}$ depth, and in the clay+silt sized fraction, it varied from 77.2 $\mathrm{Mg} \mathrm{ha}^{-1}$ at $0-30 \mathrm{~cm}$ depth to $50.8 \mathrm{Mg} \mathrm{ha}^{-1}$ at $80-100 \mathrm{~m}$ depth. Similar findings were reported by Koppad and Janagoudar (2018)who concluded that among the different land use land cover classes in Karnataka, maximum SOC was sequestered (184.08 t/ha), in the dense forest of Haliyal taluk, followed by horticulture plantation (143.80 t/ha) and in Joida taluk, maximum SOC was stored in dense forest (120.36 t/ha) followed by open land (73.80 t/ha) and concluded that deciduous forest sequestered more soil organic carbon compared to the evergreen forest due to more contribution from the leaf litter in a deciduous forest.
Maximum SOC was retained in the silt+clay sized fraction $(<53 \mu \mathrm{m})$ in all the land uses with reference to the different soil fractions. Soil organic carbon in silt + clay -sized fraction size class which represents the stable carbon is related to tree density. Similar findings were reported by Saha et al. (2010) who studied the carbon storage in different soil size fractions in different land uses such as home gardens, natural forest, agriculture of Kerala and reported that the Total C stock (Mgha $\left.{ }^{-1}\right)$ was highest in forests (176.6), followed by managed tree-based systems, and lowest in the rice-paddy field (55.6). Maximum carbon was stored in the < $53 \mu \mathrm{m}$ fraction, the most stable form of $C$ in soil, in land-use systems such as forests and small-sized home garden. The SOC concentration depends on the plant productivity since management leading to input of organic matter into the soil augments the active carbon fraction (Sahoo et al. 2019) and continuous inputs of easily decomposable leaf litter all through the year in forests might have resulted in a high value of labile carbon. In our study, among all the land uses, agriculture land use recorded the lowest soil organic carbon content and stocks. Most of the agricultural soils contain lower SOC pools than their counterparts under natural ecosystems. Tillage practices lead to mechanical breakdown of the soil aggregates resulting in loss of carbon that was once encapsulated within the aggregates, whereas minimization of the soil disturbance leads to carbon accumulation. Similar results were reported by Manjaiah et al. (2010) that intensive agriculture results in a decreased amount of soil organic carbon. Less amount of organic carbon under cultivated land might be due to the effects of tillage in combination with reduced soil organic matter inputs and complete removal of crop residues from cultivated fields (Adeboye et al., 2011). Dorji et al. (2014) also reported that fir forest soils in Eastern Himalayas in Bhutan recorded higher mean SOC density values than other land use types and in the first $20 \mathrm{~cm}$ soil surface, the percentage of mean SOC density was lowest under agricultural lands (34\%).

\section{Conclusion}

Soil organic carbon is an indicator of both soil quality and environmental stability. The study has generated baseline data on the soil organic carbon under different land uses in the dominant soil series of the Cauvery Delta zone of Tamil Nadu, India. At $0-30 \mathrm{~cm}$ depth, the forest land use stored the maximum SOC stock in the different size fractions viz. macro-sized fraction $\left(73.0 \mathrm{Mg} \mathrm{ha}^{-1}\right.$ ), a micro-sized fraction $(76.0 \mathrm{Mg}$ $\left.\mathrm{ha}^{-1}\right)$ and silt+clay sized fraction $\left(77.0 \mathrm{Mg} \mathrm{ha}^{-1}\right)$ in Madukkur series. Agriculture land use registered the lowest SOC stock. Among the different size fractions, silt+clay sized fraction $(<53 \mu \mathrm{m})$ retained the maximum SOC in all the land uses. In Kalathur series also, maximum soil organic carbon stock was recorded in forest land use. Hence, suitable soil management 


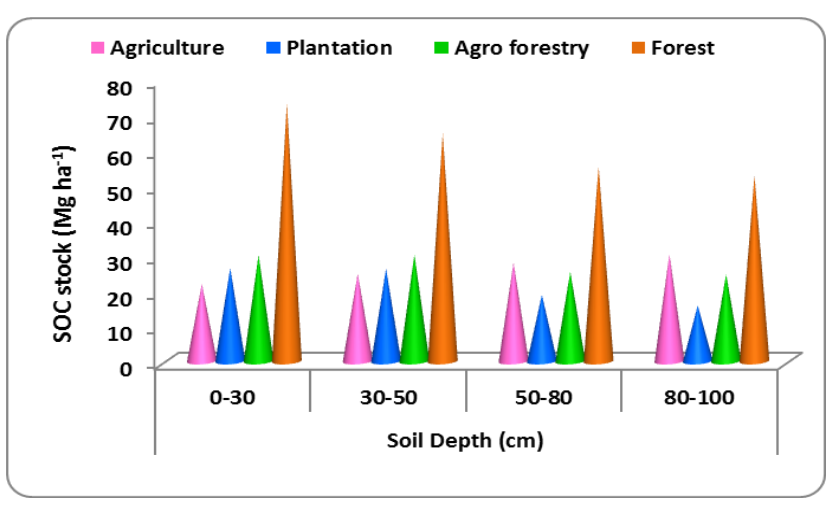

Fig. 2. Effect of land use on Soil Organic Carbon Stock

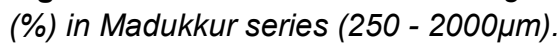

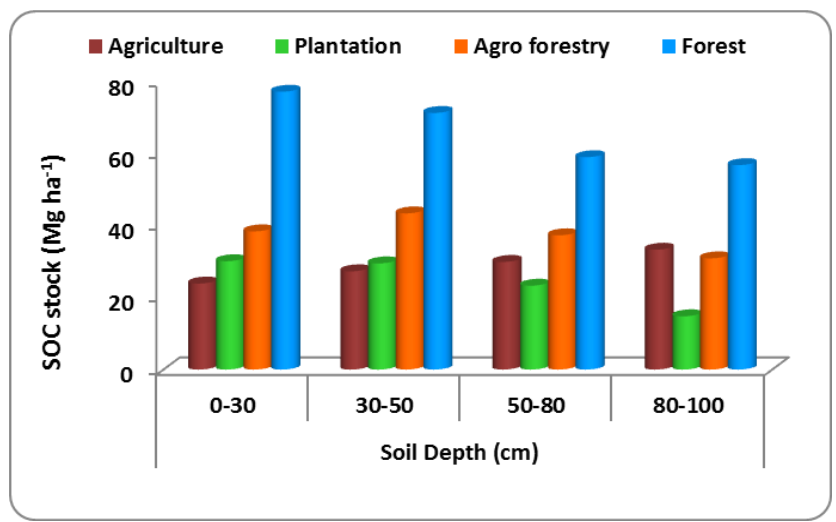

Fig. 4. Effect of land use on Soil Organic Carbon Stock (\%) in Madukkur series (<53 $\mu \mathrm{m})$.

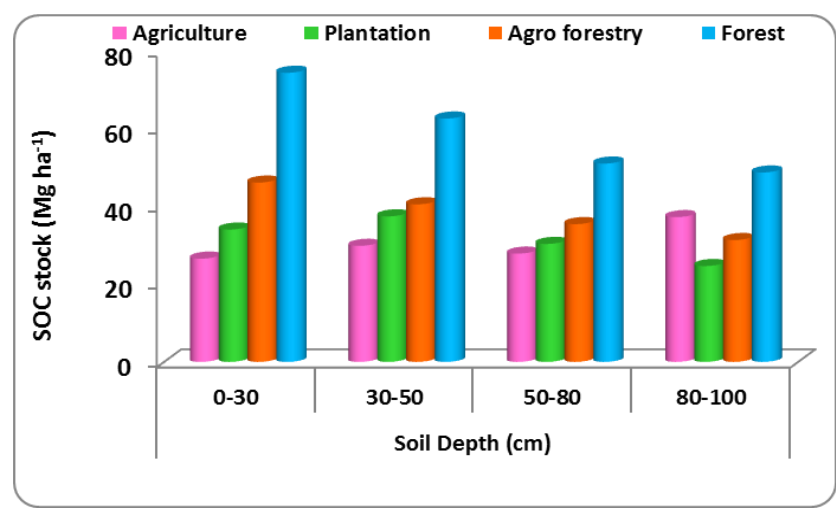

Fig. 6. Effect of land use on Soil Organic Carbon Stock (\%) in Kalathur series (53 - $250 \mu \mathrm{m})$.

practices are required to be adopted to increase soil organic carbon stock in different land-use systems.

\section{ACKNOWLEDGEMENTS}

The authors are thankful to Director General, Indian Council of Forestry Research and Education, Dehradun for providing financial support to undertake the project work.

\section{Conflict of interest}

The authors declare that they have no conflict of interest.

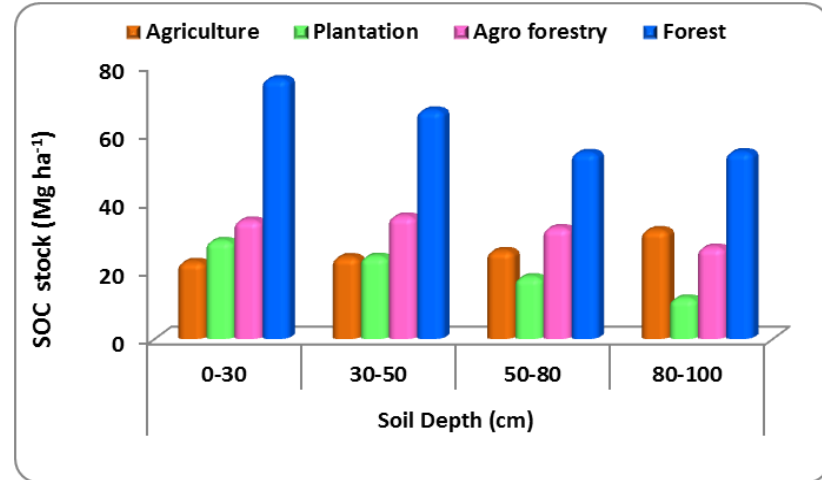

Fig. 3. Effect of land use on Soil Organic Carbon Stock (\%) in Madukkur series (53 - $250 \mu \mathrm{m})$.

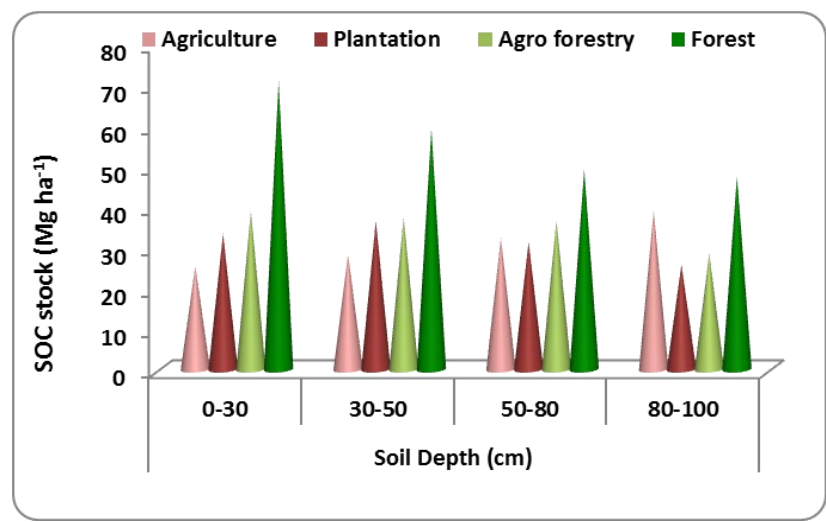

Fig. 5. Effect of land use on Soil Organic Carbon Stock

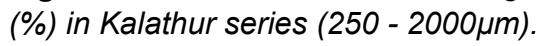

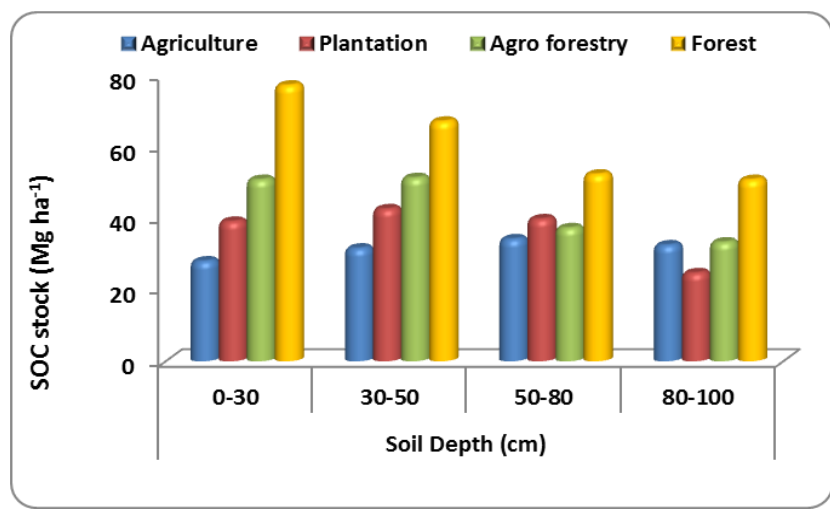

Fig.7. Effect of land use on Soil Organic Carbon Stock $(\%)$ in Kalathur series $(<53 \mu \mathrm{m})$.

\section{REFERENCES}

1. Adeboye, M.K.A, AbdullahiBala, Akim O, Osunde, Anthony, O, Uzoma, AyoJ.Odofin and Baba A. Lawal (2011). Assessment of soil quality using soil organic carbon and total nitrogen and microbial properties in tropical agroecosystems'. Agricultural Sciences, 2 (1):34-40.

2. Bajracharya, R.M., Sitaula, B.K., Shrestha, B.M., Awasthi., K.D., Balla, M.K. and Singh. B. R. (2004). Soil organic carbon status and dynamics in the central Nepal Middle Mountains. Journal of Institute of Forestry. 12, 28-44.

3. Benbi, D.K., Brar, K, Toor, A.S, and Singh, P. (2014). Total and labile pools of soil organic carbon in cultivated 
and undisturbed soils in northern India. Geoderma. 237238: 149-158.

4. Clara, L., Fatma, R., Viridiana, A. and Lieal, W. (2017). Soil organic carbon: the hidden potential. Food and Agricultural Organization of the United Nations, Rome, Italy.

5. Devagiri, G. M., S. Money, S. Singh, V. K. Dadhawal, P.Patil, A. K. Khaple, A. S. Davakumar and S. Hubballi (2013). Assessment of above ground biomass and carbon pool in different vegetation types of southwestern part of Karnataka, India using spectral modeling. Tropical Ecology, 54: 149-165.

6. Dorji, T., O.A. Inakwu, J. Damien, Field, and lan C. Baillie (2014). Digital soil mapping of soil organic carbon stocks under different land use and land cover types in montane ecosystems, Eastern Himalayas. Forest Ecology and Management., 318: 91-102.

7. Haile, S.G., Nair, P.K.R. and Nair. V. D. (2010). Carbon storage of different soil-size fractions in Florida silvopastoral systems. Journal of Environmental Quality.,37: 1789 $-1797$.

8. IPCC (2003). Good Practice Guidance for Land Use, Land Use Change and Forestry. Published by the Institute for Global Environmental Strategies (IGES) for the IPCC. Publishers Institute for Global Environmental Strategies, Japan.

9. Kenye, A., Sahoo, U.K., Singh, S.L. and Gogoi, A. (2019). Soil organic carbon stock of different land uses of Mizoram, Northeast India. AIMS Geosciences, 5 (1): 25-40.

10.Koppad, A.G. and Tikhile, P. (2014). Role of forest on carbon sequestration in soils of Joida and Karwartaluka of Uttara Kannada district. Indian Forester., 140(3): 260-264.

11.Koppad, A.G., and Janagoudar, B. S. (2018). Effect of Land Use Land Cover on Soil Carbon Sequestration in Haliyal Taluka of Uttara Kannada District. Indian Forester., 144, 3: 234-237.

12.Lal, S.H., Bajracharya, R.M. and Sitaula. B. K. (2012). Forest and Soil Carbon Stocks, Pools and Dynamics and Potential Climate Change Mitigation in Nepal, 1, 800-811.

13.Manjaiah, K.M., Sarvendra Kumar, M.S., Sachdev, P. and Sachdev, Datta. S.C. (2010). Study of Clay - Organic
Complexes. Current Science., 98(7): 915-921.

14.Quéré, C., Andrew, R. M., Canadell, J. G., Sitch, S., Korsbakken, J. I., Peters, G. P., Manning, A. C., Boden, T. A., Tans, P. P., Houghton, R. A., Keeling, R. F., Alin, S., Andrews, O. D., Anthoni, P., Barbero, L., Bopp, L., Chevallier, F., Chini, L. P., Ciais, P., Currie, K., Delire, C., Doney, S. C., Friedlingstein, P., Gkritzalis, T., Harris, I., Hauck, J., Haverd, V., Hoppema, M., Goldewijk, K. K., Jain, A. K., Kato, E., Wiltshire, A. J. \&Zaehle, S. 2016. Global Carbon Budget. Earth System Science Data, 8: 605-649.

15.Saha, S.K., Nair, P.K.R., Nair, V.D. and Kumar, B. M. (2010). Carbon storage in relation to soil size fractions under tropical tree based land use systems. Plant Soil., 328: 433-446.

16.Sahoo, U.K, Singh, S.L., Gogoi, A., Kenye, A., and Sahoo, S.S. (2019). Active and passive soil organic carbon pools as affected by different land use types in Mizoram, Northeast India. PLOS ONE., 14(7): e0219969. https://doi.or g/10.1371/journal. pone.0219969.

17.Scharlemann, J.P.W., Tanner, E., Hiederer, R. and Kapos, V. (2014). Global soil carbon: understanding and managing the largest terrestrial carbon pool. http:// www.tandfonline.com/doi/abs/10.4155/cmt.13.77

18.Six, J., Conant, R.T., Paul, E.A. and Paustian, K. (2002). Stabilization mechanisms of soil organic matter: Implications for C-saturation of soils. Plant and Soil., 241: 155176.

19.Venkanna, K., Uttam Kumar Mandal, J., SolomonRaju, K. L., Sharma, V. Ravikant, Adake, Pushpanjali, Sanjeeva Reddy, Rahul. Masane, N., Venkatravamma, and PedaBabu (2014). Carbon stocks in major soil types and land-use systems in semiarid tropical region of southern India. Current Science., 106 (4): 604-611

20.Walkley, A. and Black. C. A. (1934). An examination of the Degtjareff method for determining soil organic matter and a proposed modification of the chromic acid titration method. Soil Sci.,40: 233- 243.

21.Wiesmeier, M., Lutzow, V, Sporlein, P. (2015). Land use effects on organic carbon storage in soils of Bavaria: The importance of soil types. Soil Tillage Res., 146: 296-302. 